\title{
Comparative study of Spanish and Italian terrestrial small mammal coenoses from different biotopes in Mediterranean peninsular tip regions
}

\author{
M. Cagnin*§, S. Moreno $\dagger$, G. Aloise*, G. Garofalo*, R. Villafuerte $\dagger$, P. Gaona $\dagger$ and M. Cristaldi \\ * Department of Ecology, University of Calabria, 87036 Arcavacata di Rende (CS), Italy, † Estacion Biologica de Doñana, \\ Av.da Maria Luisa, s/n, Pab.Perù 41013 Seville, Spain and $\ddagger$ Department of Animal and Human Biology, University 'La \\ Sapienza', 00185 Rome, Italy
}

\begin{abstract}
A comparison of terrestrial small mammal coenoses belonging to nine different biotopes in the tips of the Iberian and Italian peninsulas was carried out using the pitfall trapping method. The influence of both habitat type and peninsular effect on composition of small mammal coenoses was analysed. In Southern Italy, 203 specimens belonging to seven species were trapped: Suncus etruscus (Savi, 1822), Crocidura suaveolens (Pallas, 1811), C. leucodon (Hermann, 1780), Microtus savii (de Sélys-Longchamps, 1838), Apodemus sylvaticus (L., 1758), A. flavicollis (Melchior, 1834) and Mus musculus domesticus Schwarz \& Schwarz, 1943. In Southern Spain 428 specimens belonging to five species were trapped: Suncus etruscus, Crocidura russula (Hermann, 1780), Microtus duodecimcostatus (de Sélys-Longchamps, 1839), Apodemus sylvaticus and Mus spretus Lataste, 1883. The relative density of small mammals
\end{abstract}

occurring in the nine Spanish sampling stations was twice that recorded in the Italian stations; however the number of species recorded in the different biotopes show similar mean values, ranging from three to five in Andalusia and from three to six in Calabria. Apodemus sylvaticus was the dominant species in the Calabrian stations, whereas Crocidura russula prevailed in Andalusia. The biotic diversity values are very similar in the Calabrian and Andalusian biotopes. By contrast, the Insectivora/Rodentia ratio was always higher in Andalusia. The more xerophytic biotopes showed greater similarities between the communities in Southern Spain and Southern Italy, while the cooler biotopes differed between these two peninsulas.

Key words. Small mammal communities, habitat type, peninsular effect, sclerophyll biome, Italy, Spain.

\section{INTRODUCTION}

The 'peninsular effect' that is linked to lower species richness in the peninsulas as compared to the mainland regions has been extensively reported by many authors (see Means \& Simberloff, 1987). There are conflicting hypotheses regarding the determinant factors in establishing the impoverishment of species apparent in peninsular tips. These hypotheses are categorized into two major groups. The first attributes impoverishment to peninsularity per se, underlies a decrease in species richness of any peninsula since the 'immigration-extinction' hypothesis proposes that peninsular geometry favours a high extinction rate but a low immigration rate (Simpson, 1964; MacArthur \& Wilson, 1967).

The second set of hypotheses emphasize the importance of habitat in the determination of species richness, suggesting that minor habitat features in the tip of the peninsulas, provoke a lower richness in species (Taylor \& Regal, 1978).

$\S$ Correspondence: Mara Cagnin, Dipartimento di Ecologia, Università della Calabria, 87030 Arcavacata di Rende (CS), Italy.
It has been noted, in fact, that the qualitative and quantitative structure of terrestrial small mammal coenoses are influenced by local ecological characteristics of the habitats: e.g. type and structure of vegetational cover (Saint Girons, 1977; Orsini, 1981; Huntley \& Inouye, 1987), orohydrographic structure (Cagnin et al., 1996), successional stage (Dulic, 1963; Ferns, 1979; Andersen, 1980; Wolk \& Wolk, 1982; Fons et al., 1992), and the degree and type of human intervention (Kirkland, 1977; Pizzolotto et al., 1991; Halle, 1993; Amarena, Contoli \& Cristaldi, 1994).

To evaluate the relevance of the two hypotheses, we have utilized a method which compared the biocenotic similarity among terrestrial small mammals coenoses of nine different biotopes respectively in Andalusia (Southern Spain) and Calabria (Southern Italy). These Mediterranean areas correspond to the tips of the Iberian and Italian peninsulas, respectively. They are located west of the Palearctic region and both areas are exposed to similar climatic factors.

According to the second group of hypotheses, if species richness is determined by habitat characteristics, then the diversity of species between paired habitats in the two regions should result to be similar. If no relation exists 


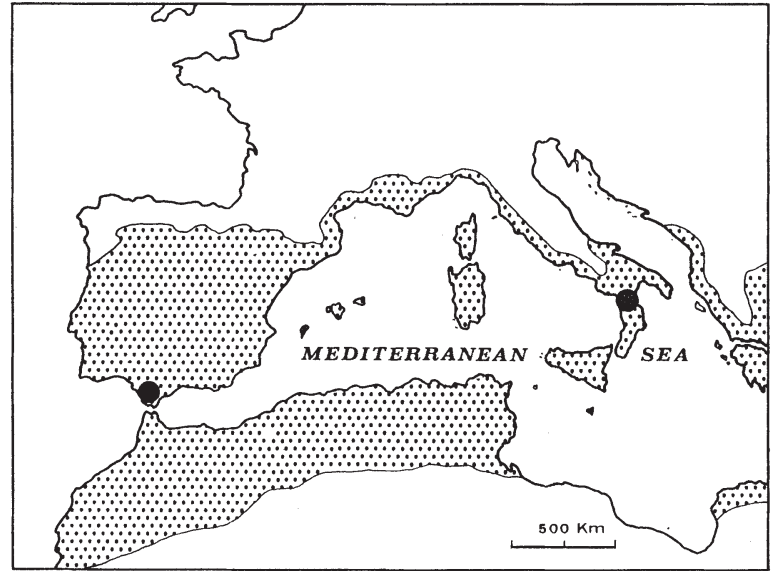

FIG. 1. Localization of the two studied areas in the Mediterranean basin. Dotted area: Mediterranean bioclimate.

between paired habitats in the two peninsular tips, then the peninsularity per se hypothesis becomes the determinant factor in the impoverishment of the species.

\section{STUDY AREAS AND METHODS}

\section{Study areas}

Small mammals from the nine biotopes were sampled from areas $c .1,800 \mathrm{~km}$ distant and both between $36^{\circ}$ and $40^{\circ} \mathrm{N}$, in Calabria (Italy) and Andalusia (Spain) as illustrated in Fig. 1.

The two areas studied belong to the sclerophyll biome of the Mediterranean biogeographical region. The area in Calabria was within the Ligure-Campano-Calabrian bioclimatic region while the area in Andalusia belongs to the Betica bioclimatic region (Rivas-Martinez, 1987). Both areas are characterized by thermo- and meso-mediterranean bioclimate (Peynado Lorca \& Rivas-Martinez, 1987; Biondi $\&$ Baldoni, 1991), with an annual average temperature above $16^{\circ} \mathrm{C}$, with abundant rainfall occurring during the winter months while the summers are hot and dry (Alès, 1986; Granados, 1987; Brandmayr et al., 1991).

Nine different biotopes, being the most representative of the ecological landscape of each country, were selected. Trapping stations were established for each biotope (Table 1) and were paired between the Italian (I) and Spanish (S) stations based on the following criteria:

\section{Marshlands (Ma-I and Ma-S)}

Plain alophitic areas characterized by wide annual fluctuations of ground water, dominated by vegetation belonging to the order Juncetalia maritimi Br.-B1. 1931.

Ma-I: Marshland located at the mouth of the Crati river, north of the Ionian coast.

Ma-S: Salado del Moron. Marshland (marisma) located at the mouth of the Guadalquivir river, near Sevilla.

\section{Pine woods (Pw-I and Pw-S)}

The secondary mature woods composed of Pinus pinea were located in plain areas, in Spain are associated with mediterranean shrubland belonging to the Halimio halimifolii-Sthauracanthetum genistoidis Rivas-Martinez et al. 1980 association and in Italy they are associated with littoral plants belonging to the order Ammophiletalia BraunBlanquet, Pinto Da Silva \& Rozeira 1972.

Pw-I: Pine woods located near the mouth of the Crati river in the North Ionian coast.

Pw-S: Pine woods in the locality of Corral del Venado $16 \mathrm{~km}$ from the sea, inside the established sand dune near Doñana National Park (Rivas-Martinez et al., 1980).

\section{Xerophytic mediterranean shrublands (Xs-I and Xs-S)}

Xerophytic mediterranean shrublands are located in plain areas. These shrubs are made up mainly of Rosmarinum officinalis in Italy and Halimium halimifolium in Spain. They are ascribed to the order Rosmarinetalia Br.-Bl. 1931 and to the association Halimio halimifolii-Sthauracanthetum genistoidis, respectively.

Xs-I: Rosemary shrubland located in the Satanasso river banks in the North Ionian coast.

Xs-S: Shrubland ('monte blanco') of the locality of Trebejil, near the occidental border of Doñana National Park, $15 \mathrm{~km}$ from the sea (Rivas-Martinez et al., 1980).

\section{Arid streams (As-I and As-S)}

Mediterranean shrublands (class Quercetea ilicis Br-B1. 1947) located near short and temporary streams.

As-I: Short streams in the Torrente Avena left bank, situated in North Ionian coast. Open woods with understory plants of the order Quercetalia-ilicis Br.-Bl. (1931) 1936 characterize this shrubland.

As-S: Arroyo de La Miel near the western border of the Doñana National Park. This area is comprised of a stream valley formed by the outlet into the Atlantic Ocean, and located in the steady external dunes with shrub vegetation of the association Rubio longifoliae-Coremetum albi RivasMartinez et al., 1980.

\section{Stream borders (Sb-I and Sb-S)}

Mountain streams are associated with variable water flow during the year. The predominant vegetation in the banks are made up mainly of species of the Nerio-Tamaricetae Br.B1. \& Bolós 1957 class.

Sb-I: Avena river bank flows the North Ionian coast. Sb-S: Oleander (Nerium oleander) vegetation is located on the border of Guadalete river in the 'Sierra de Grazalema' Natural Park.

\section{Mediterranean Maquis (Mm-I and Mm-S)}

The typical Mediterranean shrubland (class Quercetae ilicis) belongs to the orders Pistacio-Rhamnetalia alaterni RivasMartinez 1975 and Quercetalia ilicis. 
TABLE 1. Geographical and ecological characteristics of Andalusian sample sites (-S) and Calabrian sample sites (-I)

\begin{tabular}{|c|c|c|c|c|c|c|}
\hline Sample sites & Code site & $\begin{array}{l}\text { Altitude } \\
\text { (m) }\end{array}$ & $\begin{array}{l}\text { Precipitation } \\
\quad(\mathrm{mm})\end{array}$ & Slope & Exposure & $\begin{array}{l}\text { Vegetation } \\
\text { cover }(\%)\end{array}$ \\
\hline \multirow[t]{2}{*}{ Ma - Marshlands } & Ma-S & 5 & 651 & 0 & l & 90 \\
\hline & Ma-I & 0 & 507 & 0 & l & 90 \\
\hline \multirow{2}{*}{ Pw - Pine woods } & $\mathrm{Pw}-\mathrm{S}$ & 60 & 472 & 0 & l & 70 \\
\hline & $\mathrm{Pw}_{\mathrm{W}} \mathrm{I}$ & 0 & 507 & 0 & l & 55 \\
\hline \multirow{2}{*}{ Xs - Xerophytic shrubs } & $\mathrm{Xs}-\mathrm{S}$ & 50 & 546 & 0 & l & 85 \\
\hline & Xs-I & 40 & 624 & 0 & l & 85 \\
\hline \multirow[t]{2}{*}{ As - Arid streams } & As-S & 10 & 472 & 5 & S-SW & 85 \\
\hline & As-I & 180 & 624 & 20 & $\mathrm{E}$ & 75 \\
\hline \multirow[t]{2}{*}{$\mathrm{Sb}-$ Stream borders } & $\mathrm{Sb}-\mathrm{S}$ & 960 & 2223 & 0 & l & 80 \\
\hline & $\mathrm{Sb}-\mathrm{I}$ & 280 & 624 & 0 & l & 80 \\
\hline \multirow[t]{2}{*}{ Mn - Mediterranean maquis } & $\mathrm{Mn}-\mathrm{S}$ & 700 & 906 & 25 & S-SE & 80 \\
\hline & Mn-I & 180 & 893 & 45 & $\mathrm{NE}$ & 95 \\
\hline \multirow[t]{2}{*}{ Hw - Holm oak woods } & $\mathrm{Hw}-\mathrm{S}$ & 1200 & 920 & 25 & S-SE & 85 \\
\hline & Hw-I & 350 & 1160 & 40 & NW & 90 \\
\hline \multirow[t]{2}{*}{ Cw1 - Cork oak woods 1} & Cw1-S & 640 & 1377 & 25 & S-SW & 90 \\
\hline & Cw1-I & 350 & 1141 & 30 & SW & 90 \\
\hline \multirow[t]{2}{*}{ Cw2 - Cork oak woods 2} & Cw2-S & 450 & 1377 & 5 & S-SW & 60 \\
\hline & Cw2-I & 390 & 1141 & 30 & S-SW & 85 \\
\hline
\end{tabular}

Mm-I: Mediterranean shrubland located on the left bank of the Trionto river running to the North Ionian coast. Mm-S: Mediterranean shrubland located in the 'Sierra de Grazalema' Natural Park at Puerto del Acebuche.

\section{Holm oak woods (Hw-I and Hw-S)}

The mature woods of this area are dominated by Quercus ilex (class Quercetea ilicis). Shrub vegetation is characterized by species belonging to the orders Pistacio-Rhamnetalia alaterni and Quercetalia ilicis.

Hw-I: Holm oak wood located on the right edge of the Rianni river towards the North Ionian coast.

Hw-S: Holm oak wood located in the 'Sierra de Grazalema' Natural Park in Ballesteros.

\section{Cork oak woods-I (CwI-I and CwI-S)}

The arboreal-brushed vegetation belonging to the alliances Quercion brotero-suberis (Br.-Bl., Pinto Da Silva \& Roziera 1956) Rivas Martínez 1975 in Spain and Quercion ilicis Br.B1. 1936 in Italy, are representatives of the subserial stages of climax woods (see Testi \& Lucattini, 1994).

Cw1-I: Cork-oak wood situated near the village of Fuimefreddo Bruzio on the North Thyrrenian coast. Vegetation has been modified by fire, with species belonging to the class of Cisto-Lavanduletea Br.-B1. 1940, characteristic not only of degradated stages of the cork-oak wood, but also, in certain climatic and edaphic conditions of reconstruction stages of these woods (Testi \& Lucattini, 1994).

Cw1-S: Climax cork-oak wood identified as 'alcornocal de umbria' (see Ibarra Benlloch, 1993), is typical of 'Los Alcornocales' Natural Park, in Pasada de la Cierva. The areas sampled were near a stream with a typical Rododendron ponticum baetica formation.

\section{Cork oak woods 2. (Cw2-I and Cw2-S)}

Degraded Quercus suber woods with poor underwood are typical of the degradation stages (see Testi \& Lucattini, 1994) of the alliances Quiercion brotero-suberis in Spain and Quercion ilicis in Italy.

Cw2-I: Cork-oak wood located near the village of Fiumefreddo Bruzio on the North Thyrrenian coast. The vegetation is composed of mediterranean (Quercion ilicis/ Quercetalia ilicis) and submediterranean woods (Quercetalia pubescentis $\mathrm{Br} .-\mathrm{Bl} ., 1931)$.

Cw2-S: Cork-oak wood identified as 'alcornocal de solana' (see Ibarra Benlloch, 1993) is located in the 'Los Alcornocales' Natural Park, in Tajo de Domingo.

\section{Methods}

Pitfall traps were used to census small mammal communities because they offer the advantage of sampling almost all of the species of terrestrial small mammals, including Insectivores, which are difficult to capture by other kinds of traps (Puceck, 1969; Pankakoski, 1979). These traps, $18 \mathrm{~cm}$ high and $9 \mathrm{~cm}$ in diameter, were adapted from 1.5-21 plastic containers and filled with a mixture of formalin, vinegar and water preserving as solution.

Fifteen traps were set at $10 \mathrm{~m}$ intervals at each of the nine trapping stations in the two studied areas. The traps remained permanently throughout the year from June 1992 to May 1993, in order to normalize for the phenological and dispersal habits characteristic of each species.

The traps were checked and refreshed monthly and the number of active traps were recorded, according to a previously determined schedule (Cagnin, 1991; Cagnin et al., 1996).

The annual abundance of small mammal species present in each area was calculated according to the following formula: 


$$
T=(N \times 100) /(t \times n),
$$

where $N$ is the number of each species captured with 1 trap, $n$ the number of nights in which trapping was carried out, and $t$ is the number of total traps (Pucek, 1969 and Pankakoski, 1979, modified).

The last parameter was obtained considering the total number of active traps (traps still active after one month: value $=1$ ), partially active traps (traps not completely active after one month, e.g. empty of preserving solutions, full of water, leaves, slightly displaced, etc.: value $=0.5$ ) and lost traps (traps not found or completely displaced from their original site: value $=0$ ). A value of 0.5 was assigned to partially active traps since specimens often found within indicated that they were active for an estimated $50 \%$ of the time.

To calculate biotic diversity (BD) the Gini-Simpson Index (Gini, 1912) was used, since it is considered to be less influenced by sample size:

$$
\mathrm{BD}=1-\Sigma p^{2}
$$

where $p$ indicates the capture frequency of each species, expressed as the ratio between the $T$ value of the species and the $T$ value of the whole sample.

Furthermore, the ratio between the number of Insectivores and the number of Rodents (Herrera, 1974; Contoli, 1980) in each trapping station was estimated:

$$
\mathrm{I} / \mathrm{R}=\text { Insectivora/Rodentia. }
$$

$T$ values of each genera in the eighteen trapping stations were used to determine the associations using cluster analysis statistics of an SPSS/PC plus 3.0 software package. The Squared Euclidean distance was used to measure the distance between the cluster of cases and the average linkage between groups was used as the clustering method (UPGMA).

\section{RESULTS}

The small mammal communities in the nine selected sites in Calabria and Andalusia were composed of the same five genera.

In Calabria 203 specimens belonging to seven species were captured. Of these three were Insectivores: Suncus etruscus (Savi, 1822), Crocidura suaveolens (Pallas, 1811) and C. leucodon (Hermann, 1780), while Rodents made up the other four species: Microtus savii (de Sélys-Longchamps, 1838), Apodemus sylvaticus (L., 1758), A. flavicollis (Melchior, 1834) and Mus musculus domesticus Schwarz \& Schwarz, 1943 (Table 2). In Andalusia 428 specimens of five species were captured, two of Insectivores: Suncus etruscus and Crocidura russula (Hermann, 1780) and three of Rodents: Microtus duodecimcostatus (De SélysLongchamps, 1839), Apodemus sylvaticus and Mus spretus Lataste, 1883 (Table 3). Differences in abundance were evident between the two regions. Overall, the abundance of small mammals (index $T$ ) occurring in Andalusia trapping stations was almost double that recorded in Calabria $(\bar{T}=$ $1.00 \pm 0.56$ v. $0.47 \pm 0.25$ ).

In Andalusian stations, the highest abundance was reported in the most humid biotopes, mainly cork-oak and holm-oak woods. Conversely the lowest values were found in the most xerophytic stations situated close to sea level, while the marshlands presented an intermediate abundance of species. In Andalusia, Apodemus sylvaticus together with Crocidura russula were dominant in the holm-oak and corkoak wood stations, while $C$. russula was recorded in all the biotopes prevailing in five out of the nine stations, especially in more densely covered biotopes. In the Spanish marshland Suncus etruscus was the most abundant species (Table 3 ).

A similar trend was also found in Calabria. In this case, the highest relative density was reported in the arboreal stations composed of thick bush growth, while the lowest densities were recorded in stations situated in more open vegetational structures, located at lower levels. Apodemus sylvaticus was the dominant species in eight out of the nine Calabrian stations studied (Table 2).

When the entire trappings were considered, the genus Apodemus was dominant in Italy (63\% in Calabria v. $30 \%$ in Andalusia, $\left.\chi^{2}=11.51, P<0.01\right)$ while the genus Crocidura predominated in Spain (44\% in Andalusia v. $19 \%$ in Calabria, $\left.\chi^{2}=9.32, P<0.01\right)$ (Fig. 2).

In Spain, the $T$ value of the sites was positively correlated to altitude $(R=0.835, P<0.005)$ and precipitation $(R=$ $0.732, P<0.025)$, while in Italy no such correlation was found.

Although two more species were found in the Italian biotopes, the number of species recorded in the biotopes of both countries showed similar mean value $4.22 \pm 0.67$ (range $=3-5)$ in Andalusia and 4.33 \pm 1.11 (range $=3-6)$ in Calabria.

In addition, the mean biotic diversity value $(\overline{\mathrm{BD}})$ was very similar among the Calabrian $(\overline{\mathrm{BD}}=0.53 \pm 0.11)$ and Andalusian $(\overline{\mathrm{BD}}=0.55 \pm 0.08)$ areas in both cases the values were not statistically significant.

On the contrary, the Insectivora/Rodentia (I/R) ratio was higher in all stations of Andalusia $(\overline{\mathrm{I} / \mathrm{R}}=1.72 \pm 0.85)$ as compared to that of Calabria $(\overline{I / R}=0.35 \pm 0.21)$. In fact, in Andalusia the number of Insectivores was higher than that of Rodents in seven of the nine biotopes, while in Calabria the number of Rodents was always greater than that of Insectivores (Student test: $t=4.67 ; P<0.0002$ ).

It is interesting to note that Lacertids were regularly found in pitfall traps with the species Podarcis sicula being predominant in Calabria and Psammodromus algirus, Lacerta lepida, Podarcis hispanica in Andalusia. When the ratio between the number of Lacertids or Insectivores and the total number of captures (small mammals + Lacertids) in each station was considered, an inverse correlation between Insectivores and Lacertids frequency was evident (Fig. 3; $r=-0.75, P<0.001)$. In Andalusia the mean value of $0.188 \pm 0.173$ was obtained for the Lacertids and $0.481 \pm 0.148$ for Insectivores while in Calabria these values were $0.444 \pm 0.177$ and $0.131 \pm 0.042$ respectively. The highest Lacertid frequencies were recorded in the driest biotopes (Xs-I, Sb-I, Pw-S, Xs-S and As-S) of both areas.

The cluster analysis performed on all eighteen stations (Fig. 4) showed the presence of three clusters, A, B, C and two subclusters, $C_{1}$ and $C_{2}$, which were separated on the basis of different ecological characteristics. 


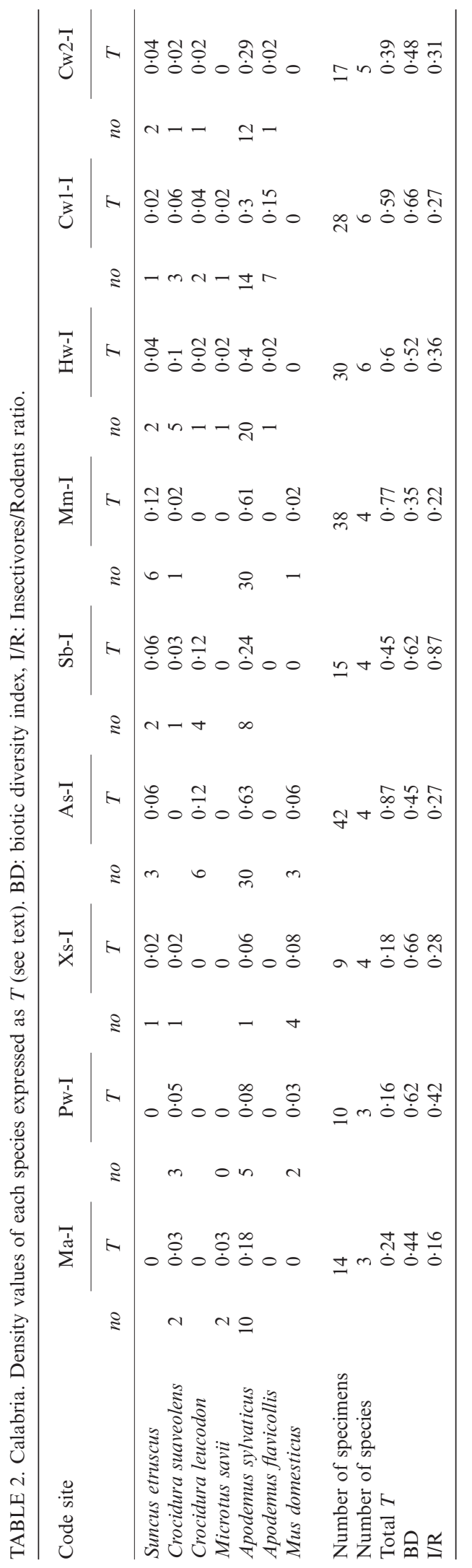


IIIO M. Cagnin et al.

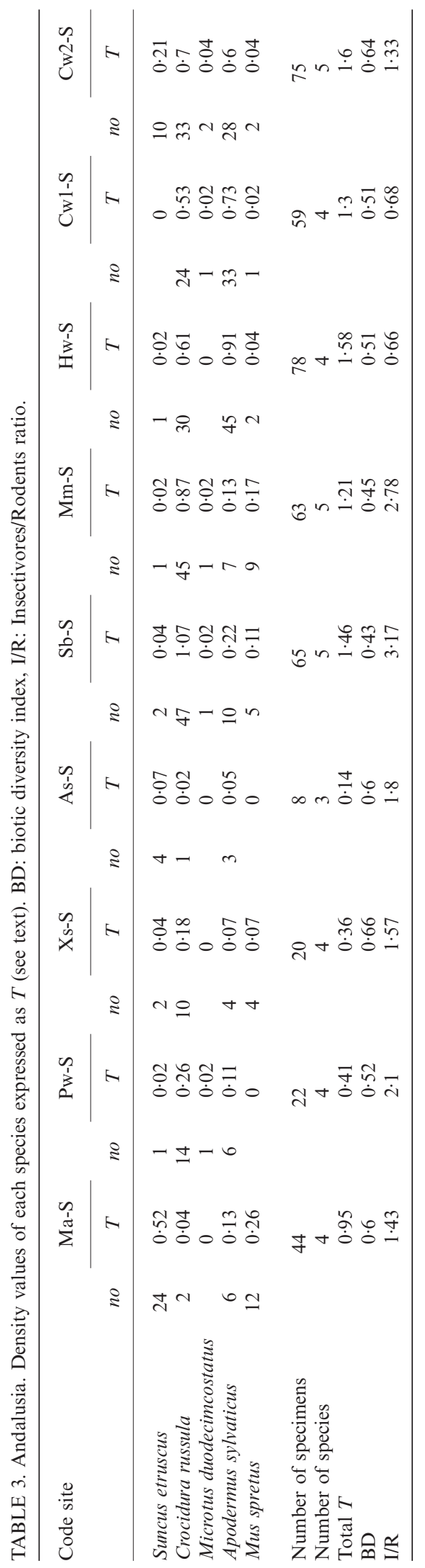




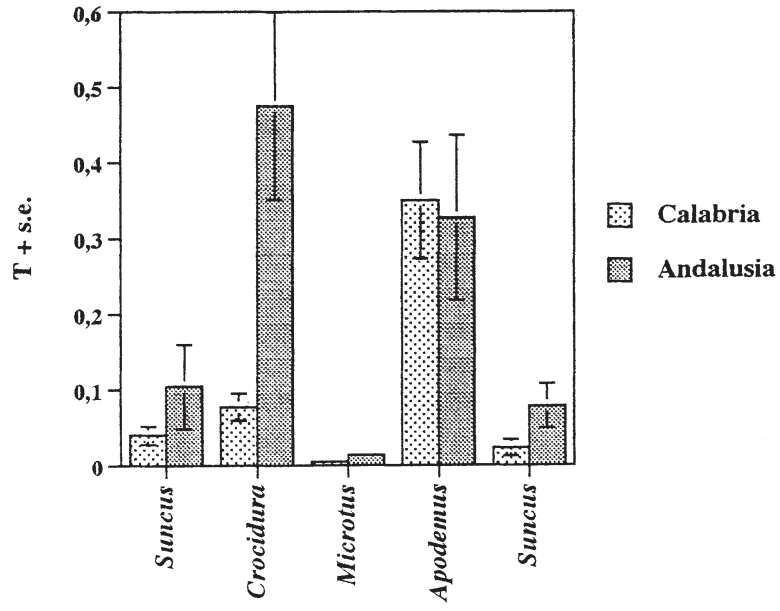

FIG. 2. Comparison among density values of the five small mammal genera found in Andalusia and Calabria, expressed as $T$ (see text). Bars indicate the standard error values.

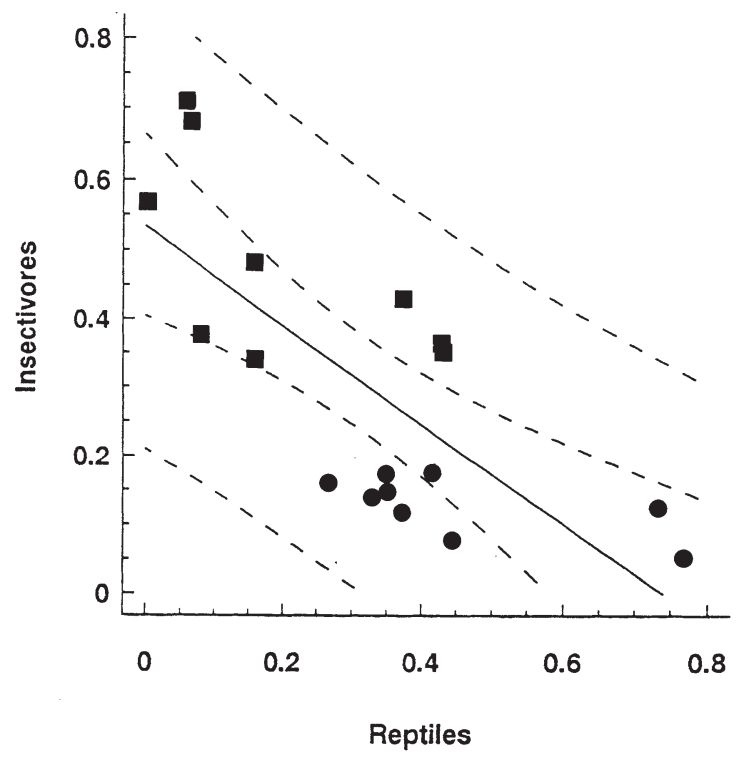

FIG. 3. Correlation among Lacertids and Insectivores in the nine Andalusian and Calabrian sample sites, calculated as number of Lacertids (or Insectivores)/number of specimens found in each sample site. Andalusian data; Calabrian data.

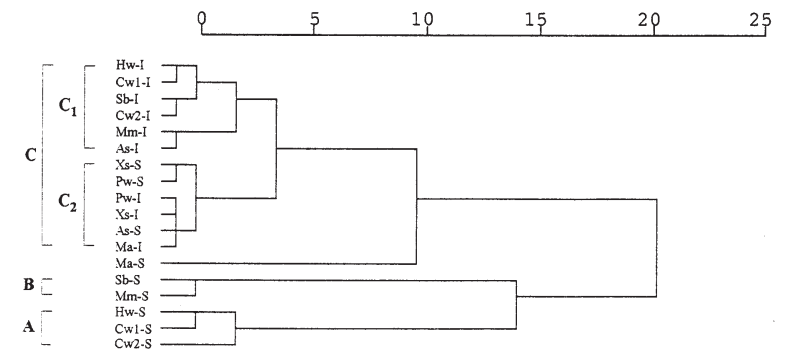

FIG. 4. Dendrogram showing the affinities among Andalusian and Calabrian sample sites.
A. This cluster comprises the arboreal Spanish stations with holm oak and cork oak woods found at higher altitude, with mature and good preserved vegetation and high rainfall values. The small mammal communities are characterized by the highest total density values $(T>1)$ and by two dominant species (Crocidura russula and Apodemus sylvaticus) that show similar frequencies.

B. This cluster comprises the Spanish shrub stations, mediterranean maquis (Mm-S) and stream borders (SbS), both at higher altitude and with high mean rainfall values; the mammal community, which is almost identical in the two stations, is characterized by the presence of only one dominant species (Crocidura russula) and by high total density values $(T>1)$.

C. This cluster comprises all the Italian stations and four Spanish stations. The Spanish marshland (Ma-S) is considered to belong to this group even if its community shows a very distinct structure, due to the presence of Mus spretus and Suncus etruscus as dominant species. The Italian marshland is characterized by lower water level variations and its community shows less pioneer characteristics.

$\mathrm{C}_{1}$. This subcluster comprises Italian stations (corresponding to the Spanish stations of cluster A and B), located at higher altitude and with high yearly mean rainfall values; the small mammal community is characterized by low density values $(T<1)$ and Apodemus sylvaticus is the dominant species.

$\mathrm{C}_{2}$. This subcluster comprises the more xeric Italian and Spanish stations, which are characterized by lower mean yearly rainfall and localized at lower altitudes. Noteworthy, is the high similarity between Italian and Spanish pine woods $(\mathrm{Pw})$ and xerophytic mediterranean shrublands (Xs). The small mammal communities are the poorest from both number of species as well as density, there is only a dominant species and precisely an Insectivore in Andalusia (Crocidura russula or Suncus etruscus) and a Murid in Calabria (Apodemus sylvaticus or Mus musculus domesticus).

In conclusion, in the two study areas it is possible to identify two different kinds of communities, in relation to the various biotic (mainly vegetation structure) and abiotic (precipitations, altitude) features:

1. Xerophytic communities (biotopes $\mathrm{Ma}, \mathrm{Pw}, \mathrm{Xs}, \mathrm{As}$ ): which is characterized by a very low density of specimens, belonging to few species, with a dominant species, and a high affinity among Italian and Spanish stations;

2. Cooler communities (biotopes: $\mathrm{Sb}, \mathrm{Mm}, \mathrm{Hw}, \mathrm{Cw}$ ): which is characterized by higher density, higher number of species, with one or two dominant species.

\section{DISCUSSION}

The 'peninsular effect' is evident in both Andalusia and Calabria with regard to the presence of Insectivores and Rodents; indeed only $36 \%$ and $59 \%$ of the species that are present in the North of Italian and Iberian peninsulas, respectively, reach the extreme tip of the two peninsulas 
(Amori et al., 1993; Rodríguez, 1993). The lower values reported for Spain are mainly due to the mesophilous component of the theriocoenoses.

It is noteworthy that, considering the ecological preferences of the entire species pool, Insectivores and Rodents constitute only $22 \%$ of all small mammal species in Andalusia, while in Calabria they comprise $50 \%$ of the total pool. The transversal arrangement of the Spanish high mountain chains may be responsible for hindering the many mesophilous species from reaching the southern tip of the Iberian peninsula, since the deciduous forest biome is interrupted. Only some species, especially those typical of cool climates (i.e. Sorex araneus, Dicrostonyx sp., Galemys pyrenaicus) during the Pleistocene period were able to reach the southern tip of the Spanish peninsula (Sesé, 1994). Since the climatic conditions became drier during the Higher Pleistocene mainly in the south (Sesé, 1994; Iza et al., 1985), these species are currently extinct or limited in northern Spain.

In Italy, the longitudinal arrangement of the Apennines which extend to the tip of the peninsula, allows for the continuity of deciduous forest biome, sustaining the current distribution of mesophilous species such as Sorex spp. and Clethrionomys glareolus in the south.

The difference in arrangement of the mountain chains on the two peninsulas (transverse on the Iberian and longitudinal on the Italian) could also be responsible for the higher number of Iberian endemic species (20\%) compared to that found in Italy $(9 \%)$ (Wilson \& Reeder, 1993).

In the mediterranean areas that we have studied, the mesophilous species are not considered to be determinant in these communities. In fact, only A. flavicollis, a species considered as restricted to mesophilous wooded habitats (Hoffmeyer, 1983) was found in the Calabrian holm oak and cork oak woods. Indeed, this species has been recently found in various Italian mediterranean wooded habitats (Cagnin et al., 1996).

In spite of the greater number of species caught in South Italy, no important differences were found between the structure of the small mammal communities in Andalusia and Calabria. In particular, the mean number of species and biotic diversity are very similar between the communities of the two countries. They both present structures typical of Mediterranean environments which are characterized by Microtine scarcity and abundance of Apodemus sylvaticus and Mus in certain biotopes (Saint Girons, 1973; Fa, Shaw \& Santana, 1992; Cagnin et al., 1996) and the prevalence of a lonely species that reflects a poorer and scanty habitat (Odum, 1983, Herrera \& Hiraldo, 1976; Cody et al., 1983).

The abundance of small mammals is the variable that undergoes evident modifications among both biotopes and peninsular regions studied and this modification is almost exclusively reflected by the higher density of Crocidura in Spain. Among the biotopes, the most remarkable differences were found in the Spanish stations. Both precipitation and altitude appear to be significantly correlated with the differences in abundance in the Spanish biotopes. Elevated precipitation and mild temperatures typical of higher altitudes produce both better environmental conditions and resource availability that are responsible for the higher abundance in animal communities (Tilman, 1982). Similarly, in 183 localities in Spain by Barbosa \& Benzal (1996) high correlation between small mammals abundance and precipitation were reported. However, they also found that latitude is the main factor underlying differences in abundance, but they did not consider the importance of altitude, mainly in low latitudes.

In Southern Italy, no significant correlation was found between the environmental factors considered (altitude, precipitation) and small mammals abundance, probably due to the minor variation in both dependent and independent variables (abundance and environmental factors).

In conclusion the most important difference between the Andalusian and Calabrian communities is the higher proportion of Insectivores in the former community. A similar trend was also outlined in studies carried out with barn owl pellets. In fact, with large samples of preyed small mammals (about 13,000 specimens) a I/R value of $0 \cdot 25$ was calculated in Andalusia (Herrera, 1974) with a value of 0.17 in Calabria (Aloise et al., 1990). According to Contoli (1988), the decreasing of the I/R values from North to South of Italy could be caused by the increasing number of animals that compete for food with Insectivores, such as Lacertids. We have considered this suggestion as a valid explanation of Insectivores found in the two areas are suggestive, but this obviously needs deeper and more extensive investigation.

\section{ACKNOWLEDGMENTS}

We are grateful to J. Ayala, A. Barbieri, S. Manna, C. Milazzo, M. C. Quintero, R. De Rango for their help during the field trapping; to L. Bernardo and A. Testi, respectively for the floristic and vegetational characterization of the biotopes; R. Pizzolotto for the suggestions in the interpretation of dendrograms.

The research was supported by the following funds: (1) 'Azione Integrata Italia-Spagna, MURST', coordinated by M. Cristaldi e S. Moreno; (2) 'Progetto Strategico CNRPSAC', coordinated by P. Brandmayr.

\section{REFERENCES}

Alès, E.E. (1986) Cartografia de la vegetaciòn arborea de la Reserva Biològica de Doñana y evoluciòn del matorral de las arenas estabilizadas. Tesis doctoral, Univ. Sevilla.

Aloise, G., Barbieri, A., Cagnin, M. \& Aloise, P. (1990) Primo allestimento della "Collezione microteriologia della Calabria". Atti VI Conv. Naz. "A. Ghigi”, Torino, 22-24 giugno 1989. Mus. Reg. Sc. Nat. Torino, 245-248.

Amarena, D., Contoli, L. \& Cristaldi, M. (1994) Coenotic structure, skull asymmetries and other morphological anomalies in small mammals near an electronuclear power plant. Histrix, 5(1993), $31-46$.

Amori, G., Angelici, F.M., Frugis, S., Gandolfi, G., Groppali, R., Lanza, B., Relini, G. \& Vicini, G. (1993) Vertebrata. Checklist delle specie della fauna italiana, 110 (ed. by A. Minelli, S. Ruffo and S. La Posta). Calderini, Bologna.

Andersen, D.C, MacMahon, J.A. \& Wolfe, M.L. (1980) 
Herbivorous mammals along a mountain sere: community structure and henergetics. J. Mammal., 61, 500-519.

Barbosa, A. \& Benzal, J. (1996) Diversity and abundance of small mammals in Iberia: peninsular effect or habitat suitability? $Z$. Säugetierkunde, 61, 236-241.

Biondi, E. \& Baldoni, M. (1991) Bio-climatic characteristics of the Italian peninsula. Proc. Symp. 'Effect of Atmospheric pollutants on climate and vegetation', Taormina (Italy) 26-29 September 1991, pp. 225-250.

Brandmayr, P, Codogno, M. \& Pizzolotto, R. (1991) Basi ecologiche per la mappatura delle risorse naturali in Calabria: biomi ed unità ambientali minori lungo la sezione Catena Costiera - Sila Grande - Sila Greca. S.It.E. Atti, 12, 389-393.

Cagnin, M. (1991) Ecological distribution of terrestrial small mammals in Southern Italy. European Congress of Mammalogy. Lisboa, Portugal, 18-23 March 1991, 102.

Cagnin, M, Aloise, G., Garofalo, G., Milazzo, C. \& Cristaldi, M. (1996) Les communautes de petit Mammifères de terre des trois "fiumare" de la Calabre (Italie du sud). Vie Milieu, 46, 319-326.

Cody, M.L., Breytenback, G.J., Fox, B., Newsome, A.E., Quinn, R.D. \& Siegfried, W.R. (1983) Mineral nutrients in Mediterranean ecosystems. S. Afr. Nat. Scient. Prog. Rep. 71, 91-114.

Contoli, L. (1980) Borre di Strigiformi e ricerca teriologica in Italia. Natura Montagna, 3, 73-94.

Contoli, L. (1988) La nicchia trofica di Allocco (Strix aluco) e Barbagianni (Tyto alba) in Italia: acquisizioni e problemi. Naturalista sicil., S. IV. XII (Suppl.), 129-143.

Dulic, B. (1963) On small mammals frequency in different forests associations. Bull. Scient.: 8, 5-6.

Fa, J.E, Shaw, E. \& Santana, A. (1992) Habitat associations of small mammals in a Southern Spanish fir forest. Mammalia, 56, 478-481.

Ferns, P.N. (1979) Successional changes in the small mammals community of a young larch plantation in south west Britain. Mammalia, 43, 439-452.

Fons, R., Grabulosa, I., Feliu, C., Mas-Coma, S., Galan-Puchades, M.T. \& Comes, A.M. (1992) Postfire dynamics of a small mammal community in a Mediterranean forest (Quercus suber). Proc. Int. Workshop 'Fire in Mediterranean ecosystems' (ed. by L. Trabaud and Prodon), pp. 259-270.

Gini, C. (1912) Variabilità e mutabilità. Studi Econ. Giur., Fac. Giurispr., Univ. Cagliari, anno III (II).

Granados, M.G. (1987) Transformaciones històricas de los ecosistemas del Parque Nacional de Doñana. Tesis doctoral, Univ. Sevilla.

Halle, S. (1993) Wood mice (Apodemus sylvaticus L.) as pioneers of recolonization in a reclaimed area. Oecologia, 94, 120-127.

Herrera, C.M. (1974) Regimen alimenticio de Tyto alba en España sudoccidental. Ardeola, XIX, 359-393.

Herrera, C.M. \& Hiraldo, F. (1976) Food-niche and trophic relationships among European owls. Ornis Scand, 7, 29-41.

Hoffmeyer, I. (1973) Interaction and habitat selection in the mice Apodemus flavicollis and Apodemus sylvaticus. Oikos, 24, 108-116.

Huntley, N. \& Inouye, R.S. (1987) Small mammal population of an old field chronosequence successional patterns and association with vegetation. J. Mammal. 68, 738-745.
Kirkland, G.L., Jr (1977) Responses of small mammals to the clearcutting of northern Appalachian forest. J. Mammal. 58, 600-609.

Ibarra Benlloch, P. (1993) Naturaleza y hombre en el sur del campo de Gibraltar: un análisis paisajistico integrado. Junta de Andalucia, Consejeria de Cultura y Medio Ambiente, Agencia de Medio Ambiente.

Iza, J.B., Castien, E., Mendiola, I.T. \& Pemán, E. (1985) Algunos aspectos de la ecología de los micromamíferos del País Vasco. Munibe (Ciencias Naturales), 37, 101-110.

MacArthur, R.H. \& Wilson, E.O. (1967) The theory of island biogeography. Princeton University Press, Princeton, N.J.

Means, D.B. \& Simberloff, D. (1987) The peninsula effect: habitatcorrelated species decline in Florida's herpetofauna. J. Biogeogr, 14, 551-568.

Odum, E.P. (1983) Basic ecology. CBS College Publishing.

Orsini, P. (1981) Premier échantillonnages de micromammifères en Provence. Mammalia, 45, 187-197.

Pankakoski, E. (1979) The cone trap - a useful tool for index trapping of small mammals. Ann. Zool Fennici, 16, 144-150.

Peynado Lorca, M. \& Rivas-Martinez, S. (Eds.) (1987) La vegetacion de España. Univ. De Alcala de Henares, Secr. Gen. Serv. Publicaciones.

Pizzolotto, R., Mingozzi, A., Cagnin, M., Tripepi, S., Aloise, G., Barbieri, A., Scalzo, A. \& Brandmayr, P. (1991) Effetti della ceduazione periodica del castagneto sulle comunità di micromammmiferi, Uccelli, Rettili e Coleotteri Carabidi. S.IT.E. Atti, 12, 389-393.

Pucek, Z. (1969) Trap response and estimation of numbers of shrews in removal catches. Acta Theriologica, XIV, 403-426.

Rivas-Martinez, S. (1987) Memoria del mapa de series de vegetacion de España 1: 400.000. ICONA.

Rivas-Martinez, S., Costa, M., Castroviejo, S. \& Valdés, E. (1980) Vegetacion de Doñana (Huelva, España). Lazaroa, 2, 5-189.

Rodríguez, J.L. (1993) Guía de campo do los Mamíferos terrestres de España. 314 pp. Omega Ed.

Saint Girons, M.-C. (1973) Les mammifères de France et du Benelux. Doin Ed., Paris.

Saint Girons, M.-C. (1977) Morphologie végétale et répartition des Mammifères. Bijdragen Dierkunde, 47, 120-130.

Sesé, C. (1994) Paleoclimatical interpretation of the quaternary small mammals of Spain. GEOBIOS, 27, 753-767.

Simpson, G.G. (1964) Species density of North American recent mammals. Syst. Zool., 12, 57-73.

Taylor, R.S. \& Regal, P.J. (1978) The peninsular effect on species diversity and the biogeography of Baja California. Am. Nat., $112,583-593$.

Testi, A. \& Lucattini, C. (1994) Contribution to the syntaxonomic knowledge of Quercus suber woodlands of Latium. Rend. Fis. Acc. Lincei, 9, 247-259.

Tilman, D. (1982) Resource competition and community structure. Princeton University Press, N.J.

Wilson, D.E. \& Reeder, D.M. (eds) (1993) Mammal species of the world: a taxonomic and geographic reference, 2nd ed, $1206 \mathrm{pp}$. Smithsonian Institute Press, Washington.

Wolk, E. \& Wolk, K. (1982) Responses of small mammals to the forest management in the Bialowieza Primeval Forest. Acta theriol., 27, 45-59. 